ISSN 1027-5495. Functional Materials, 24, No.4 (2017), p. 660-666

\title{
Poly(lactic acid) scaffolds modified by gelatin for the controlled release of tetrandrine in vitro
}

\author{
Zhang $Y e^{1,2}$ \\ ${ }^{1}$ Department of Pharmaceutical Sciences, Zibo Vocational Institute, \\ Zibo, Shandong 255314, China \\ ${ }^{2}$ Research Center of Traditional Chinese Medicine, \\ Tianjin University of Traditional Chinese Medicine, Tianjin300193, China
}

Received August 20, 2017

To mimic natural extracellular matrix architecture, tetrandrine-loaded poly(L-lactic acid) scaffolds modified by gelatin were prepared via phase separation, solvent replacement and freeze-drying. The purpose of this work was to combine the biological effects of tetrandrine and the advantages of poly(L-lactic acid) scaffolds which was modified by gelatin to enhancing the mass transfer features of controlled release systems. Tetrandrine contained in the scaffolds was confirmed by X-ray photoelectron spectroscopy (XPS) and Fourier-transform infrared (FT-IR) spectroscopy. Tetrandrine did not change the morphous, crystallinity and thermodynamics of the scaffolds which demonstrated by differential scanning calorimetry (DSC), scanning electron microscopy (SEM) and X-ray powder diffractometry (XRD). The results of this study showed a sustained release with $79.15 \%$ for 188 days in vitro.

Keywords: poly(lactic acid) scaffolds, gelatin, tetrandrine, tissue engineering.

С целью воссоздания естественной архитектуры внутриклеточного матрикса методами разделения фаз, заменой растворителя и сублимационной сушки были синтезированы полимерные каркасы поли(L-молочной кислоты), модифицированные желатином и загруженные тетрандрином. Цель данной работы состояла в объединении биологического эфрфекта тетрандрина и преимуществ синтезированных каркасов для повышения характеристик массопереноса с контролируемым высвобождением лекарственного вещества (тетрандрина). Присутствие тетрандрина в синтезированных каркасах определялось методами рентгеновской фотоэлектронной спектроскопии и инфракрасной спектроскопии с Фурье-преобразованием. Методами дифференциально сканирующей калориметрии, сканирующей электронной микроскопии и рентгендазового анализа показано, что тетрандрин не изменяет морфологию, кристалличность и термодинамику образования каркасов. Результаты исследования in vitro показали, что синтезированные каркасы обеспечивают пролонгированное высвобождение 79,15\% тетрандрина в течение 188 дней.

Полімерні каркаси полі (L-молочної кислоти), модифіковані желатином для контрольованого вивільнення тетрандріна in vitro. Zhang Ye

3 метою відтворення природної архітектури внутрішньоклітинного матриксу методами розподілу фоз, заміною розчинника та сублімаційною сушкою були синтезовані полімерні каркаси полі (L-молочної кислоти), модифіковані желатином і завантажені тетрандріном. Мета даної роботи полягала в об'єднанні біологічного ефекту тетрандріна і переваг синтезованих каркасів для підвищення характеристик масопереносу з контрольованим вивільненням лікарської речовини (тетрандріна). Присутність тетрандріна в синтезованих каркасах визначався методами рентгенівської фоотоелектронної спектроскопії та інфрачервоної спектроскопії з Фур'є-перетворенням. Методами диференційно скануючої калориметрії, скануючої електронної мікроскопії та рентген-фразового аналізу показано, що тетрандрін не змінюе морфологію, кристалічність і термодинаміку створення каркасів. Результати дослідження in vitro показали, що синтезовані каркаси забезпечують пролонговане вивільнення 79,15\% тетрандріна протягом 188 днів. 


\section{Introduction}

Much interest has been generated recently in the area of tissue engineering to create biological alternatives for implants and prostheses. In this approach, a highly porous scaffold (artifical extracellular matrix) is needed to accommodate cells and guide their growth and tissue regeneration in three dimensions. Biodegradable polymers, either natural or synthetic, have been processes into scaffolds for tissue engineering [14]. Poly(lactic acid) (PLLA), a biodegradable synthetic materials, was widely used in biomedical engineering due to their innocuity, biodegradability, bioenvironmental compatibility and so on $[14,25,6]$. It was therefore approved by the Food and Drug Administration (FDA) for certain human clinical applications such as surgical sutures and some implantable devices. Recently, porous PLLA scaffolds were widely investigated in osteoblastic [32], cranial bone [22] , corneal [1], chondrocyte [2] tissue engineering, etc. However, one disadvantage of PLLA scaffold was the complications resulting from the accumulation of lactic acid produced in the process of degradation.

Growth factor is mostly water soluble protein from human or animal. Its price is expensive, and its biological property is unstable. Thus, its loading on the scaffolds has certain difficulty. Additionally, excessive dose of growth factor may induce tumor cell growth. Antibiotics are also used in engineering scaffolds for antibacterial and anti-infection in vitro [12]. However, the pharmacological action of antibiotics is only simple antibacterial. Antibiotics have no physiological activity. Some effective components in traditional Chinese medicine has a function similar to that of the cytokines and the corresponding pharmacological effects, and the price is low, the physical and chemical properties is relative stability. Thus, they show good prospects for application as substitutes of cytokines. Tetrandrine (Tet), a bis-benzylisoquinoline alkaloid isolated from the dried root of the natural Chinese herb Stephania tetran$d r a$ which used as an effective agent for rheumatic arthritis and rheumatoid arthritis exhibits a variety of pharmacological activities such as anti-inflammatory, antioxidant, anti-fibrotic and anticancer activities, antiplatelet aggregation, $\mathrm{Ca}^{2+}$ channel block, immunosuppressive, and free radical scavenging effects $[11,13,17$, $23,24,30]$. Consequently, it has effective function in the treatment of many diseases including pulmonary diseases, hepatic fibrosis, arthritis, silicosis and so on $[9,10,16,20]$. Tet has also shown antidepressant-like effect by regulating the central monoaminergic neurotransmitter system and the levels of BDNF [7] . Ac- cording to previous literature, low concentration of Tet (1-2.5 $\mathrm{mg} / \mathrm{L}$ ) promotes proliferation, activity and glycosaminoglycan and collagensecreting of chondrocyte. Thus, Tet has great prospective future in cartilaginous tissue engineering applications [5]. Compared with control PLLA films, Tet loaded in the poly (L-lactic acid) (PLLA) films could reduce the inflammatory response in macrophages by regulating the mRNA expression and protein expression, and significantly inhibit inflammatory reaction in 4, 12 weeks after implanting in rats. Therefore, Tet could enhanced the biocompatibility of PLLA films [21].

The purpose of the present work was to prepare Tet-loaded PLLA scaffolds modified by gelatin and investigate the controlled release of tetrandrine in vitro. PLLA scaffolds modified by gelatin, as biomimetic surface modifier could elicit controlled cellular adhesion and maintain differentiated phenotypic expression [4], were prepared via phase separation, solvent replacement, freeze-drying. Then, Tet which presents anti-inflammatory activities and physiological activities similar to cytokine was loaded on PLLA scaffolds modified. Alkalescence and anti-inflammatory activities of Tet could relieve complications resulting from the accumulation of lactic acid produced in the process of degradation. The drug with specific properties could be sustained delivered to the necessary site of action, and thus repair reconstituted cartilage tissue and maintain its phenotype and cellular function. X-ray photoelectron spectroscopy (XPS) and Fourier-transform infrared (FT-IR) spectroscopy were measured to evaluate the formulation of modified PLLA scaffolds and Tet-loaded PLLA scaffolds. Differential scanning calorimetry (DSC), scanning electron microscopy (SEM) and X-ray powder diffractometry (XRD) were performed to compare the physicochemical properties. On the other hand, drug content and release behaviors were performed to evaluate sustained release characteristics of Tet-loaded PLLA scaffolds.

\section{Materials and methods}

\subsection{Materials}

Poly(L-lactic acid) (PLLA, $M \mathrm{n}=4.32 \cdot 10^{4} \mathrm{~g} / \mathrm{mol}$ ) was kindly donated by Prof. Xue-Si Chen, Changchun Institute of Applied Chemistry Chinese Academy of Sciences. Tetrandrine (Tet) and gelatin were purchased from SigmaAldrich Co. (St Louis, USA). HPLC grade acetonitrile were supplied by Merck \& Co., Inc. (Beijing, China). Other materials and solvents used were of analytical reagent grade. 


\subsection{Preparation of PLLA scaffolds}

On the basis of the theory of thermally induced phase separation (TIPS) and freeze-drying approach (FDA) [15,18,29,31], three-dimensional microporous PLLA scaffolds modified by gelatin were fabricated via phase separation, solvent replacement and freeze-drying. A typical procedure was used as following: preweighed PLLA was dissolved in tetrahydrofuran (THF) at $60^{\circ} \mathrm{C}$ to form $5 \%$ (wt/v, polymer/ THF) solution. The solution was poured into glass vials, which were then quickly put into $-80^{\circ} \mathrm{C}$ refrigerator for 24 hours to gel. The vials containing the PLLA solution was then transferred into $50 \%(\mathrm{v} / \mathrm{v})$ ethanol at $-20^{\circ} \mathrm{C}$. After 24 hours for solvent exchange, the ethanol was replaced with 5 wt \% gelatin aqueous solution for 16 hours at room temperature. Then, the gel was placed in distilled water for 2 day, exchanging with fresh distilled water three times a day, and then put into $-20^{\circ} \mathrm{C}$ refrigerator again for freezing. Afterwards, the frozen gel lyophilized in a freeze-drier for the purpose of removing water sufficiently and the PLLA scaffolds were acquired accordingly.

The fabrication of Tet-loaded PLLA scaffolds was slightly different from that of PLLA scaffolds. One needs to add 10\% Tet (wt/wt, Tet/polymer) in 5\% (wt/v, polymer/THF) polymer solution before pouring into glass vials. All other processes were identical.

\subsection{Characterization of PLLA scaffolds}

XPS measurements of PLLA scaffolds, modified PLLA scaffolds and Tet-loaded PLLA scaffolds were performed on a instrument (Perkin Elmer 5600, USA) with Al Ka radiation $(h v=1486.6 \mathrm{eV})$. The values of binding energies were calibrated with respect to $\mathrm{C} 1 \mathrm{~s}$ peak at $284.7 \mathrm{eV}$

FT-IR spectra of PLLA scaffolds modified PLLA scaffolds and Tet-loaded PLLA scaffolds were recorded on an infrared spectrometer (BIO-RAD FTS3000, USA). The samples were prepared by the potassium bromide disc method and scanned for absorbance $4000-400 \mathrm{~cm}^{-1}$.

The powder X-ray diffraction patterns of modified PLLA scaffolds and Tet-loaded PLLA scaffolds were recorded using an X-ray diffractometer (Rigaku D/max-2500, Japan). Radiations generated from $\mathrm{Cu} \mathrm{Ka}$ source and filtered through Ni filters with a wavelength of 0.154 $\mathrm{nm}$ at $20 \mathrm{~mA}$ and $36 \mathrm{kV}$ were used. The scanning rate employed was $4^{\circ} / \mathrm{min}$ over the $10-40^{\circ}$ range.

DSC thermograms of scaffolds were recorded on a differential scanning calorimeter (PERKIN-ELMER DSC 7, USA). The instrument was calibrated with indium and zinc prior to analyzing the samples under nitrogen. All ac- curately weighed samples $(2.5 \mathrm{mg})$ were placed into sealed aluminium pans and scanned at the heating rate of $10{ }^{\circ} \mathrm{C} / \mathrm{min}$ over the temperature range of $30-250{ }^{\circ} \mathrm{C}$.

Scaffolds were viewed with a scanning electron microscope (SEM, Philips XL30, Netherlands). The surface and inner microstructures were investigated on specimen surfaces and cross-sections cut in liquid nitrogen. The samples were coated with gold prior to SEM observation.

\subsection{Determination of Tet release behaviors}

Pre weighed a mounts of PLLA scaffolds were suspended in $50 \mathrm{~mL}$ of PBS (pH 7.4) buffer solution at $37^{\circ} \mathrm{C}$. At predetermined time intervals, $200 \mu \mathrm{L}$ of released solution was withdrawn for measuring, which was replenished by $200 \mu \mathrm{L}$ of fresh PBS solution to maintain a constant volume. The concentration of released Tet was monitored on a Waters 2695 series HPLC system. 20-microliter samples were injected on a reversed-phase HPLC column (Thermo $\mathrm{C}_{18}$, $250 \mathrm{~mm} \times 4.6 \mathrm{~mm}, 5 \mu \mathrm{m})$. The mobile phase consisted of a mixture of acetonitrile and water at $30: 70$ containing $0.12 \%(\mathrm{v} / \mathrm{v})$ diethylamine and $\mathrm{pH}$ value was modified at 4 by phosphoric acid $\left(\mathrm{H}_{3} \mathrm{PO}_{4}\right)$. Flow rate was adjusted to $1.0 \mathrm{~mL} / \mathrm{min}$. All samples were analyzed in triplicate at 282 $\mathrm{nm}$. The average and standard deviations were presented.

\section{Results and discussion}

\subsection{XPS}

XPS is a quantitative spectroscopic technique that measures the elemental composition, empirical formula, chemical state and electronic state of the elements that exist within a material. XPS spectra are obtained by irradiating a material with a beam of X-rays while simultaneously measuring the kinetic energy (KE) and number of electrons that escape from the top 1 to $10 \mathrm{~nm}$ of the material being analyzed. A typical XPS spectrum is a plot of the number of electrons detected (sometimes per unit time) (Y-axis, ordinate) versus the binding energy of the electrons detected (X-axis, abscissa). Each element produces a characteristic set of XPS peaks at characteristic binding energy values that directly identify each element that exist in or on the surface of the material being analyzed.

The XPS spectrum of scaffolds was shown in Figure 1. As can be discovered, PLLA scaffolds showed two XPS peaks at $284.7 \mathrm{eV}$ and 532.8 $\mathrm{eV}$ which assigned to $\mathrm{C} 1 \mathrm{~s}$ and $\mathrm{O} 1 \mathrm{~s}$ respectively. By contrast, modified PLLA scaffolds displayed a new XPS peaks at $399.5 \mathrm{eV}$ which attributed to $\mathrm{N} 1 \mathrm{~s}$ due to cyano $(-\mathrm{CONH})$ or amine $\left(-\mathrm{NH}_{2}\right)$ 


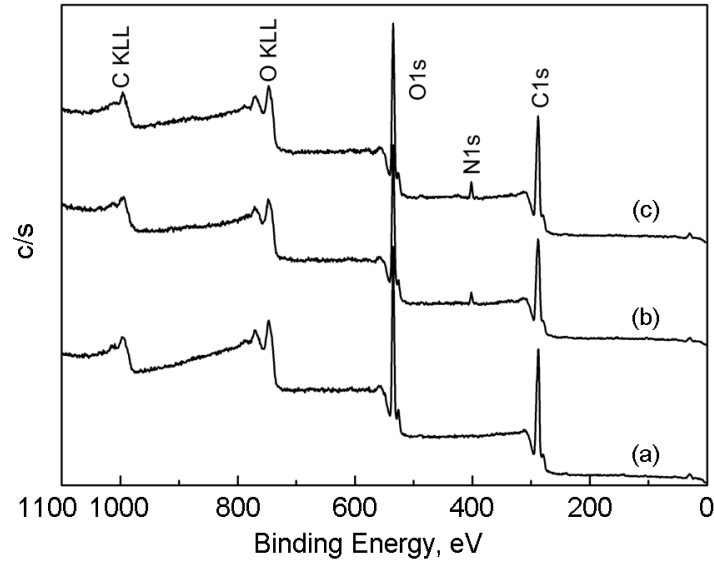

Fig 1. The XPS spectrum of PLLA scaffolds (a), modified PLLA scaffolds (b) and Tet-loaded PLLA scaffolds (c).

groups of gelatin. Therefore, gelatin was contained on the surface of PLLA scaffolds. As expected, the surface nitrogen content is larger for Tet-loaded PLLA scaffolds, compared to PLLA scaffolds modified by gelatin (Table 1). This result can be attributed to nitrogen of tertiary amines contained in Tet. In this case, Tet was contained on the surface of PLLA scaffolds.

\subsection{FT-IR spectroscopy}

FT-IR spectroscopy was utilized as another supporting evidence for the formulation of modified PLLA scaffolds and Tet-loaded PLLA scaffolds. FT-IR spectrograms of samples were given in Fig. 2. The hydroxyl (-OH), amino ($\left.\mathrm{NH}_{2}\right)$ and cyano $\left(-\mathrm{CONH}_{2}\right)$ groups gelatin stretching bands at $3000-3700 \mathrm{~cm}^{-1}$ (as the arrow in the Figure 3 shown), as well as $\mathrm{C}=\mathrm{O}$ gelatin stretching bands at $1651 \mathrm{~cm}^{-1}$ and amino gelatin characteristic absorption bands at $1557 \mathrm{~cm}^{-1}$ appeared in the FT-IR spectrogram of modified PLLA scaffolds. These were evidence of gelatin contained on the surface of modified PLLA scaffolds.

In comparison to the FT-IR spectrum of modified PLLA scaffolds, Tet-loaded PLLA scaffolds exhibits little changes in shapes, while the strength and width of characteristic absorption bands increased due to approximately the superposition of Tet and modified PLLA scaffolds.

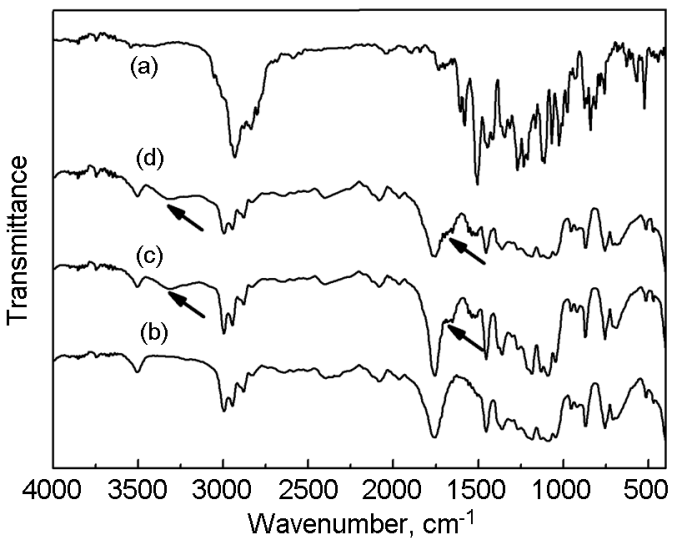

Fig. 2. FT-IR spectrum of Tet (a), PLLA scaffolds (b), modified PLLA scaffolds (c) and Tet-loaded PLLA scaffolds (d).

\section{$3.3 X R D$}

According to previous reports, modified PLLA scaffolds were conducive to cell adhesion, proliferation and function, so it has bright future in tissue engineering $[3,4,33]$. With the aim to confirm the potentiality of Tet-loaded PLLA scaffolds in chondrocyte tissue engineering, XRD was measured. XRD clearly confirmed the crystalline nature of Tet as well as the amorphous state of PLLA scaffolds (Figure 3). The crystalline peaks of modified PLLA scaffolds that at $2 \theta$ are equal to $16.6^{\circ}$ and $19.1^{\circ}$ which in accordance with the conclusion previous reported by Hideto Tsuji [19].

These peaks are comparable with a form of PLLA crystallized in a pseudo-orthorhombic unit cell of dimensions: $\mathrm{a}=1.07 \mathrm{~nm}, \mathrm{~b}=0.595$ $\mathrm{nm}$ and $\mathrm{c}=2.78 \mathrm{~nm}$ which contains two $10^{3}$ helices. It was worth noting that the shape of Tetloaded scaffolds observed on diffractograms showed no significant differences from that of modified PLLA scaffolds. Therefore, the loading of Tet did not change the crystallinity of the scaffolds.

\subsection{DSC}

DSC thermograms of modified PLLA scaffolds and Tet-loaded PLLA scaffolds were reported in Figure 4, and the melting temperature $\left(T_{\text {peak }}\right)$ and fusion enthalpy $(\Delta H)$ were listed in Table 2. As can be discovered, the thermogram of modified PLLA scaffolds showed a fusion endo-

Table 1. The elements composition of PLLA scaffolds (a), modified PLLA scaffolds (b) and Tet-loaded PLLA scaffolds (c)

\begin{tabular}{|c|c|c|c|}
\hline \multirow{2}{*}{ Samples } & \multicolumn{3}{|c|}{ element composition (\%) } \\
\cline { 2 - 4 } & $\mathrm{C}$ & $\mathrm{O}$ & $\mathrm{N}$ \\
\hline PLLA scaffolds & 65.6 & 34.4 & 0 \\
\hline modified PLLA scaffolds & 63.2 & 33.6 & 3.1 \\
\hline Tet-loaded PLLA scaffolds & 63.6 & 32.5 & 3.8 \\
\hline
\end{tabular}




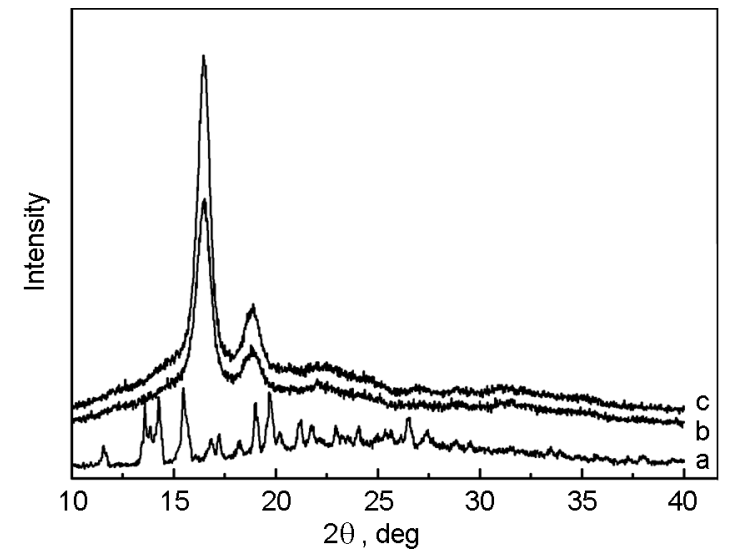

Fig. 3. X-ray diffractograms of Tet (a), PLLA scaffolds (b) and Tet-loaded PLLA scaffolds (c).

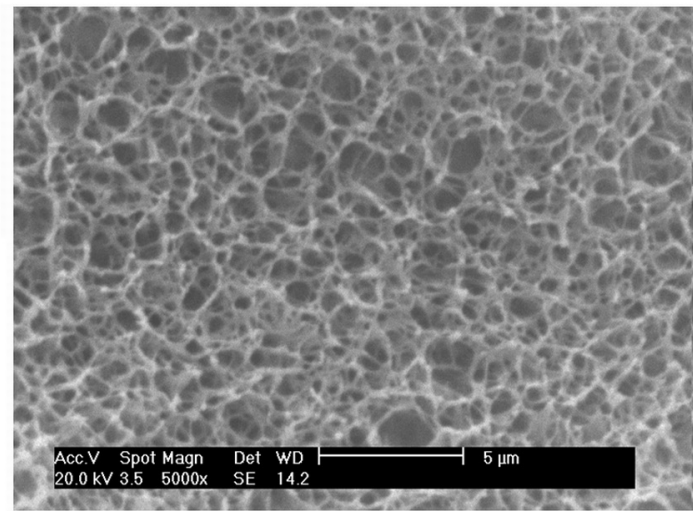

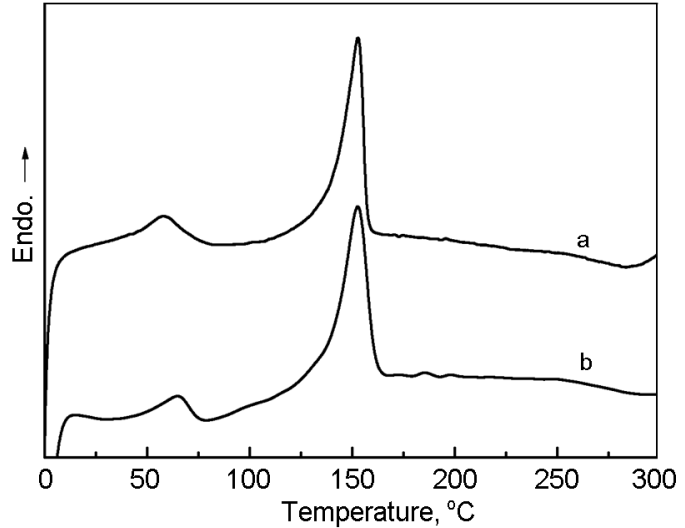

Fig. 4. DSC thermograms of modified PLLA scaffolds (a) and Tet-loaded PLLA scaffolds (b).

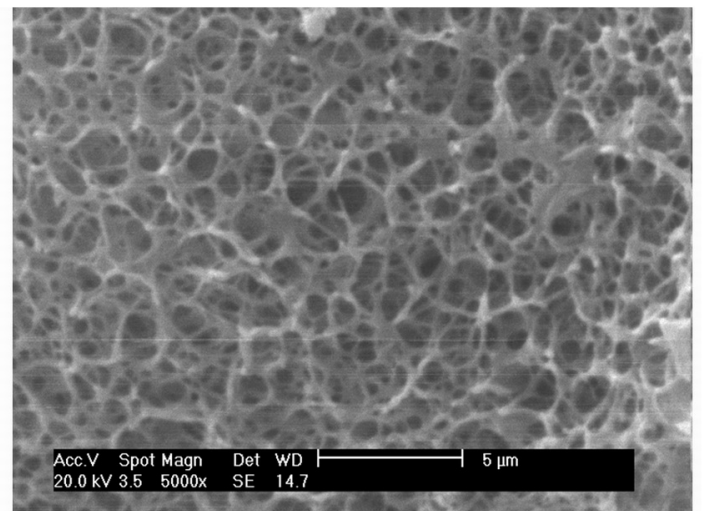

Fig. 5. SEM photographs of modified PLLA scaffolds (left) and Tet-loaded PLLA scaffolds (right).

thermic peak at $153.3^{\circ} \mathrm{C}(\Delta H=44.29 \mathrm{~J} / \mathrm{g})$ correspondent to its melting point. The thermogram of Tet-loaded scaffolds exhibits no significant difference in $T_{\text {peak }}$ and $\Delta H$ from that of modified PLLA scaffolds, which could be explained by the existent of Tet did not change the thermodynamics of the scaffolds.

\subsection{SEM}

The morphologies of the scaffolds were shown in Figure 5. What can be found was that the scaffolds all acquire network structures constructing of ultrafine fiber. Moreover, the average fiber diameter and pore size of Tetloaded PLLA scaffolds varies little with that of

Table 2. Differential scanning calorimetric data of PLLA scaffolds

\begin{tabular}{|c|c|c|c|}
\hline Samples & $T_{\text {onset }}{ }^{\circ} \mathrm{C}$ & $T_{\text {peak }},{ }^{\circ} \mathrm{C}$ & $\Delta \mathrm{H}\left(J \cdot g^{-1}\right)$ \\
\hline $\begin{array}{c}\text { modified PLLA } \\
\text { scaffolds }\end{array}$ & 140.0 & 153.3 & 44.29 \\
\hline $\begin{array}{c}\text { Tet-loaded } \\
\text { PLLA scaffolds }\end{array}$ & 139.0 & 152.7 & 49.4 \\
\hline
\end{tabular}

modified PLLA scaffolds. In other words, the molecular structure of scaffolds keeps identical after Tet containing. Therefore, the loading of Tet did not change the morphous of the scaffolds. This would be helpful for Tet-loaded scaffolds to be used in chondrocyte tissue engineering field.

\subsection{Drug release behaviors}

The drug loading content was calculated from the ratio of amount of drug containing in the PLLA scaffold and the weight of PLLA scaffold, and up to $0.652 \mathrm{mg} / \mathrm{g}$. It was worth noting that the experimental amount of loading drug is much smaller than the theoretical amount. It may be due to considerable dissolving of Tet during the process of replacing THF with 50\% $(\mathrm{V} / \mathrm{V})$ ethanol and then with distilled water. Therefore, it is of utmost importance to assay the drug loading content of Tet-loaded PLLA scaffolds. In addition, the Tet content has significant influence on the behaviors of chondrocyte. It had been proved that low tetrandrine was beneficial for chondrocyte proliferation, chondrocyte activity and chondrocyte expression, and thus for chondrocyte tissue reconstruction [26]. In this paper, the average drug 


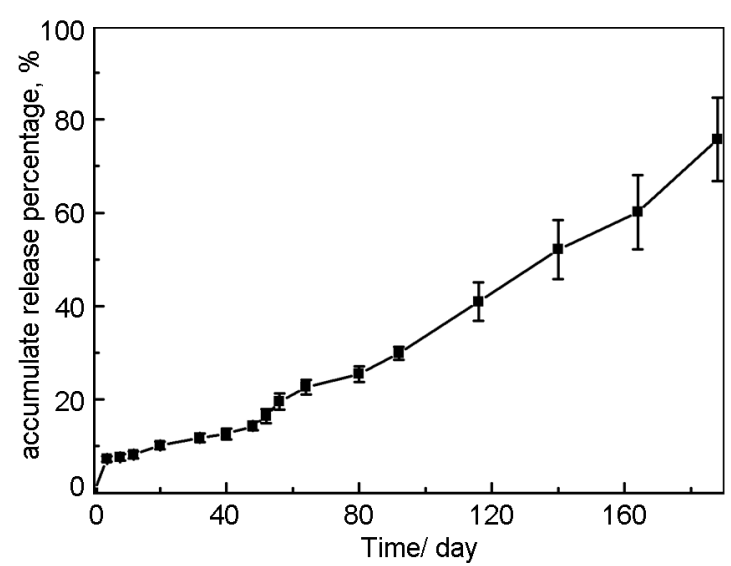

Fig. 6. In vitro release profile of Tet-loaded PLLA scaffolds modified by gelatin.

loading content of Tet-loaded PLLA scaffolds was about $0.652 \mathrm{mg} / \mathrm{g}$ which favorable for Tetloaded scaffolds using in chondrocyte tissue engineering field.

The release behaviors of Tet-loaded PLLA scaffolds were reported in Figure 6. As can be discovered, the initial burst effect was not observed in all examined samples, which confirmed that Tet-loaded PLLA scaffolds could be prepared without any residual drug on their surfaces. In the initial stage, the release rate increased slowly. After that, the drug released from the scaffolds increased apparently. Tet loaded into the pores of PLLA scaffolds showed significant sustained release characteristics of about $79.15 \%$ in 188 days. The scaffolds keep good integrity through release studies.

Drug release behaviors also have important effect on the behaviors of chondrocyte. It is generally assumed that a drug is released by several mechanics: (a) Fickian diffusion through the polymer matrix, (b) diffusion through pores in the matrix, and (c) drug liberation by polymer erosion. For Tet-loaded PLLA scaffolds, Tet is physically entrapped in PLLA matrix. And the degradation of PLLA scaffolds during the experiment period is ignorable which reported in many studies [8, 19, 27, 28,]. Therefore, it is speculated that the drug release from the scaffolds is carried out mainly through Fickian diffusion. Although the network of PLLA scaffolds which is the main diffusion barrier of Tet can swell in water solution and that should be a positive factor to improve Tet diffusion, Tet is a lipophilic alkaloid and its solubility in water is very low. This will result in the decrease of Tet release rate.

\section{Conclusions}

This study explored the potential of Tetloaded PLLA scaffolds in cartilage tissue engineering. XPS and FT-IR spectroscopy demon- strated that Tet was contained in the scaffolds. DSC, SEM and XRD confirmed that Tet did not change the morphous, crystallinity and thermodynamics of the scaffolds. Release studies revealed that Tet was released gradually, approximately $79.15 \%$ in 188 days. In addition, the scaffolds keep good integrity through release studies. Therefore, Tet-loaded PLLA scaffolds offer a considerable potential in chondrocyte tissue engineering, thus broadening the clinical application.

\section{Acknowledgements}

This research was performed by support from the National Natural Science Foundation of China (No. 30570495).

\section{References}

1. B. Aslan, S. Guler, A. Tevlek and H. M. Aydin, $J$ Biomed Mater Res B Appl Biomater, 2017. [Epub ahead of print] doi: 10.1002/jbm.b.34022.

2. G. Conoscenti, T. Schneider, K. Stoelzel, F. Carfi Pavia, V. Brucato, C. Goegele, V. La Carrubba and G. Schulze-Tanzil, Mater Sci Eng C Mater Biol Appl, 80, 449, 2017.

3. Y.-L. Cui, X.-M. Gao, J.-S. Tian and K.-D. Yao, In: 2nd International Conference on Bioinformatics and Biomedical Engineering, iCBBE, pp.1480-1483. 2008.

4. Y. L. Cui, X. Hou, A. D. Qi, X. H. Wang, H. Wang, K. Y. Cai, Y. Ji Yin and K. De Yao, J Biomed Mater Res A, 66, 770, 2003.

5. Y. L. Cui, Y. B. Zhang, X. M. Gao and K. D. Yao, Cell Research, 16, S48, 2006.

6. N. Eslahi, M. R. Hadjighassem, M. T. Joghataei, T. Mirzapour, M. Bakhtiyari, M. Shakeri, V. Pirhajati, P. Shirinbayan and M. Koruji, Int $J$ Nanomedicine, 8, 4563, 2013.

7. S. Gao, Y. L. Cui, C. Q. Yu, Q. S. Wang and Y. Zhang, Behav Brain Res, 238, 79, 2013.

8. Y. H. Gong, Q. L. Zhou, C. Y. Gao and J. C. Shen, Acta Biomaterialia, 3, 531, 2007.

9. Y. C. Hsu, Y. T. Chiu, C. C. Cheng, C. F. Wu, Y. L. Lin and Y. T. Huang, J. Gastroenterology Hepatology, 22, 99, 2007.

10. Y. C. Hsu, Y. T. Chiu, C. Y. Lee, C. F. Wu and Y. T. Huang, Canadian J. Physiology. Pharmacology, 84, 967,2006.

11. H. S. Kim, Y. H. Zhang and Y. P. Yun, Planta Medica, 65, 135, 1999.

12. H. W. Kim, J. C. Knowles and H. E. Kim, $J M a-$ ter Sci Mater Med,16, 189, 2005.

13. J. T. Liou, Z. Y. Chen, L. J. Ho, S. P. Yang, D. M. Chang, C. C. Liang and J. H. Lai, Eur.J. Pharmacology, 589, 288, 2008.

14. P. X. Ma and R. Zhang, J Biomed Mater Res, 46 , 60, 1999.

15. J. Nakamatsu, F. G. Torres, O. P. Troncoso, Y. Min-Lin, A. R. Boccaccini, Biomacromol., 7, 3345, 2006. 
16. N. Sekiya, H. Hikiami, K. Yokoyama, K. Kouta, L. Sakakibara, Y. Shimada and K. Terasawa, Biological \& Pharmaceutical Bulletin, 28,667, 2005.

17. W. K. Seow, A. Ferrante, S. Y. Li and Y. H. Thong, Int Arch Allergy Appl Immunol, 85, 404,1988.

18. H. J. Tao, J. Zhang, X. L. Wang and J. L. Gao, J. Polymer Scie.Part B-Polymer Phys., 45, 153, 2007.

19. F. Tsuji, Polymer, 43, 1789, 2002.

20. H. L. Wang, X. H. Zhang and T. H. Chang, Acta Pharmacologica Sinica, 23, 1114, 2002.

21. Q. S. Wang, Y. L. Cui, L. N. Gao, Y. Guo, R. X. $\mathrm{Li}$ and X. Z. Zhang, J Biomed Mater Res A, 102, 4098, 2014.

22. L. N. Woodard, K. T. Kmetz, A. A. Roth, V. M. Page and M. A. Grunlan, Biomacromolecules, 2017. [Epub ahead of print]

23. S. J. Wu and L. T. Ng, Biological \& Pharmaceutical Bulletin, 30, 59, 2007.

24. S. N. Wu, H. F. Li and Y. C. Lo, J.Pharm. Experim. Therapeutics, 292, 188, 2000.
25. F. Yang, R. Murugan, S. Ramakrishna, X. Wang, Y. X. Ma and S. Wang, Biomaterial, 25, 1891, 2004.

26. C. Yuan lu, Q. Ai di, L. Ke Feng and Y. Kang de, Tianjin, J. Traditional Chinese Medicine, 22,.236, 2005.

27. X. Y. Yuan, A. F. T. Mak and K. D. Yao, Polymer Degrad. Stability, 75, 45, 2002.

28. X. Y. Yuan, A. F. T. Mak and K. D. Yao, J. Appl. Polymer Scie., 85, 936, 2002.

29. C. F. Zhang, B. K. Zhu, G. L. Ji and Y. Y. Xu, J Appl Polymer Scie, 103, 1632, 2007.

30. M. Zhang, S. L. Chen, S. W. Seto, Y. W. Kwan and S. W. Chan, Pharmaceutical Biology, 47, 366, 2009.

31. J. Zhao, X. Y. Yuan, Y. L. Cui, Q. B. Ge and K. D. Yao, J.Appl.Polymer Scie., 91, 1676,. 2004.

32. G. Zhou, S. Liu, Y. Ma, W. Xu, W. Meng, X. Lin, W. Wang, S. Wang and J. Zhang, Int J Nanomedicine, 12, 7588, 2017.

33. H. G. Zhu, J. Ji and J. C. Shen, Macromol Rapid Communication,.23, 819, 2002. 